\title{
Pravastatin induces cell cycle arrest and decreased production of VEGF and bFGF in multiple myeloma cell line
}

\author{
P. J. J. Trojan a, M. S. Bohatch-Junior ${ }^{a}$, M. F. Otuki ${ }^{b}$, F. Souza-Fonseca-Guimarães ${ }^{c}$, \\ P. V. Svidnicki ${ }^{d}$,V. Nogaroto ${ }^{d}$, D. Fernandes ${ }^{b}$, E. A. Krum ${ }^{b}$ and G. M. Favero ${ }^{a *}$ \\ ${ }^{a}$ Laboratório Multidisciplinar de Ciências Biológicas e da Saúde, Universidade Estadual de Ponta Grossa - UEPG, \\ Campus de Uvaranas, Av. General Carlos Cavalcanti, 4748, CEP 84030-900, Ponta Grossa, PR, Brazil

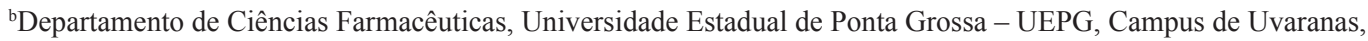 \\ Av. General Carlos Cavalcanti, 4748, CEP 84030-900, Ponta Grossa, PR, Brazil \\ 'Unit Cytokines and Inflammation, Department Infection and Epidemiology Institut Pasteur, \\ 25-28 rue du Docteur Roux, 75015, Paris, France \\ ${ }^{\mathrm{d}}$ Laboratório de Citogenética e Evolução, Departamento de Biologia Molecular, Estrutural e Genética, \\ Universidade Estadual de Ponta Grossa - UEPG, Campus de Uvaranas, Av. General Carlos Cavalcanti, 4748, \\ CEP 84030-900, Ponta Grossa, PR, Brazil \\ *e-mail: gmfavero@uepg.br
}

Received: June 23, 2014 - Accepted: October 17, 2014 - Distributed: February 29, 2016

(With 4 Figures)

\begin{abstract}
Multiple myeloma (MM) is a B cell bone marrow neoplasia characterized by inflammation with an intense secretion of growth factors that promote tumor growth, cell survival, migration and invasion. The aim of this study was to evaluate the effects of pravastatin, a drug used to reduce cholesterol, in a MM cell line.Cell cycle and viability were determinate by Trypan Blue and Propidium Iodide. IL6, VEGF, bFGF and TGF $\beta$ were quantified by ELISA and qRT-PCR including here de HMG CoA reductase. It was observed reduction of cell viability, increase of cells in G0/G1 phase of the cell cycle and reducing the factors VEGF and bFGF without influence on 3-Methyl-Glutaryl Coenzyme A reductase expression. The results demonstrated that pravastatin induces cell cycle arrest in G0/G1 and decreased production of growth factors in Multiple Myeloma cell line.
\end{abstract}

Keywords: pravastatin, Multiple Myeloma, 3-Methyl-Glutaryl Coenzyme A reductase, vascular endothelial growth factor, fibroblast growth factor.

\section{Pravastatina induz parada no ciclo celular e diminuição na produção de VEGF e bFGF em linhagem de Mieloma Multiplo}

\section{Resumo}

O Mieloma Múltiplo é uma neoplasia de linfócitos B da medula óssea, caracterizada por inflamação com uma intensa secreção de fatores de crescimento que promovem o aumento do volume do tumor, sobrevivência celular, migração e invasão. O objetivo deste estudo foi avaliar os efeitos da pravastatina, uma droga usada para reduzir o colesterol, em um linhagem de MM. O ciclo celular e viabilidade foram determinadas por Trypan Blue e iodeto de propídio. IL6, VEGF, bFGF e TGF foram quantificadas por ELISA e qRT-PCR, incluindo aqui de HMG CoA redutase. Observou-se a redução da viabilidade das células, aumento de células na fase G0/G1 do ciclo celular e redução no VEGF e bFGF, sem influência na expressão da enzima 3-Metil-Glutaril Coenzima A redutase. Os resultados demonstraram que a pravastatina induz parada no ciclo celular em G0/G1 e diminuição da produção de fatores de crescimento em várias linhas de células de Mieloma.

Palavras-chave: pravastatina, Mieloma Multiplo, 3-Metil-Glutaril Coenzima A redutase, fator de crescimento do endotélio vascular, fator de crescimento de fibroblasto.

\section{Introduction}

Multiple Myeloma (MM) is a neoplastic disease that affects antibodies-secreting B cells fully differentiated, which emerges and expands at the bone marrow (Zhan et al.,
2006; Giuliani and Rizzoli, 2007). It is the second most common hematopoietic neoplastic disease (Gadó et al., 2001). The proliferation of tumor cells in bone marrow 
results in bone destruction, suppress antibody production and lead to renal failure (Ludwig et al., 2010; Raab et al., 2009). The plasma cell adhesion on bone marrow increases the secretion of cytokines which in turn stimulate the proliferation of tumor cells contributing to their survival, migration and induce resistance to chemotherapeutic agents (Balakumaran et al., 2010; Peng et al., 2011).

The disease evolution is, partially, possible due to angiogenic mechanisms. Several studies have sought the relationship between growth factors such as FGF (fibroblast growth factor) and VEGF (vascular endothelial growth factor), to prognosis of the disease and sensitive to therapy (Greco et al., 2009). It was demonstrated that the levels of VEGF and FGF are elevated in patients with $\mathrm{MM}$ and often correlated among themselves and with other angiogenic factors (Greco et al., 2009). The binding of TGF $\beta$ (transforming growth factor $\beta$ ) to its receptor promotes activation of intracellular mediators, whose effects include immunomodulation, cell cycle and angiogenesis (Ma and Ma, 2011).

Over the last decade, Statins, the most commercial drug all over the world, prescribed as cholesterol-lowering agents, have revealed other effects, including immunomodulation, neuroprotection, improvement of bone metabolism and antitumour. The inhibition of the enzyme HMG-CoA reductase, an essential key in the biosynthesis of cholesterol (Medina 2010; Musso et al., 2011), demonstrates to be the key point to reduce cholesterol and several compounds like isopentenyladenine, dolichol, ubiquinone, geranilpirofosfato (GGPP), farnesylpyrophosphate (FPP) (Wong et al., 2007; Gauthaman et al., 2009). The reduction in synthesis of isoprenoids (GGPP, FPP), decreases it's binding to cellular proteins responsible for intracellular signaling such as Rho, Rac and Cdc42 (Roy et al., 2011; Musso et al., 2011).

The aim of this study was to assess the effects of Pravastatin, a HMG-CoA reductase inhibitor, over a MM cell line, with a focus over cell cycle, inflammatory and growth factors response, cholesterol production and pleiotropic effects.

\section{Methods}

\subsection{Cell culture}

RPMI 8226 multiple myeloma cells were grown in RPMI 1640 medium supplemented with $10 \%$ fetal bovine serum (FBS), $100 \mathrm{U} / \mathrm{mL}$ penicillin/streptomycin and $24 \mathrm{mM} \mathrm{NaHCO}$ at $37^{\circ} \mathrm{C}$ in a humidified atmosphere containing $5 \% \mathrm{CO}_{2}$. Cells were seeded at an initial density of $4 \times 10^{4}$ cells $/ \mathrm{cm}^{2}$ (RPMI 8226). Upon confluence, Pravastatin was added to the media at a concentration of 0.3-0.9 $\mu \mathrm{M}$ for different times.

\subsection{Cell viability}

Multiple Myeloma cells were plated at a density of $1 \times 10^{6}$ cells/well. Six-well tissue culture plates (Corning, NY) were used. Cells were treated with Pravastatin for three consecutive days (24h, $48 \mathrm{~h}$, and $72 \mathrm{~h}$ ). Cell proliferation and viability were determined by Trypan Blue exclusion method. Experiments were performed three times in triplicate.

\subsection{Analysis of cell cycle by flow cytometry}

Cell viability was examined by the trypan blue exclusion method. Cell cycle analysis was performed by flow cytometry. Cells were seeded at a density of $2 \times 10^{6} \mathrm{cells} / \mathrm{cm}^{2}$ (RPMI 8226). After $24 \mathrm{~h}$ cells were treated with 0.3-0.9 $\mu \mathrm{M}$ of pravastatin for up to $72 \mathrm{~h}$. At the end of the experiment, cells were trypsinized ( $0.05 \%$ trypsin in $0.02 \%$ EDTA) and washed 3 times with PBS, fixed in 70\% ethanol, and stained with propidium iodide (PI; $50 \mu \mathrm{g} / 10 \mu \mathrm{L}$, final concentration), for $30 \mathrm{~min}$ in the dark, according to the method described by Vindelov et al. (1983). All analyses were done using a FACScalibur flow cytometer (Becton Dickinson, San Jose, CA). The red fluorescence of PI was collected through a 585/42-nm band - pass filter, and the fluorescence signals were measured in a linear scale of 1024 channels. For each sample, at least 10000 events were acquired and the data were analyzed using two appropriate software (CELLQuest, Becton Dickinson, San Jose, CA; ModiFit LT 2.0). Cells in S/G $/ \mathrm{M}$ (proliferating) and $\mathrm{G}_{0} / \mathrm{G}_{1}$ phases, and hypodiploid cells (cells under death process) were analized.

\subsection{Evaluation of growth factors}

IL-6, VEGF, bFGF and TGF $\beta$ were investigated after treatment of cells in culture with pravastatin in three different concentrations: $0.3 \mu \mathrm{M}, 0.6 \mu \mathrm{M}$ and $0.9 \mu \mathrm{M}$. The samples of supernatant were withdrawn after 24,48 and 72 hours after the contact of cells with pravastatin. The supernatant was analyzed by ELISA (Enzyme Linked Immuno Sorbent Assay) to determine the levels of growth factors surveyed. The ELISA plates were read at the Life Lab reader MX range 2001 at 450/690 nm. VEGF and bFGF were quantified by RayBio ${ }^{\circledR}$ kit and IL- 6 and TGF $\beta$ by eBioscience kit ${ }^{\circledR}$ following the methodology described by the manufacturers.

\subsection{RNA extraction and quantitative RT-PCR ( $q R T-$ PCR) assays}

Total RNA from the MM cultured cells was isolated using the Illustra RNAspin Mini RNA Isolation Kit (GE Healthcare), according to the manufacturer's instructions. One microgram of total RNA were reverse transcripted using the First-Strand cDNA Synthesis Kit (GE Healthcare), as recommended by manufacturer protocol. Gene expression of HMG CoA, TGF $\beta$, VEGF, IL-6 and $\beta$ FGF was quantified by qRT-PCR in a Stratagene MxPro 3005P thermocycler. The cDNAs were amplified in duplicate PCR reactions using the Brilliant SYBR ${ }^{\circledR}$ Green Master Mix (Agilent), $10 \mu \mathrm{M}$ of each primer (HMG_f: 5' GACCATCTGCATGATGTCCA 3' HMG r: 5' TTGGACGTAAATTCTGGAACTGG 3'; TGF f: 5' GAGCCTGAGGCCGACTACTA 3', TGF_r: 5' GGGTTCAGGTACCGCTTCTC 3'; VEGF f: 5' CCTCCGAAACCATGAACTTT 3', VEGF_r: 5' GCAGTAGCTGCGCTGATAGA 3'; IL6_f: 5' CTCAGCCCTGAGAAAGGAGA 3', IL6_r: 5' TGATTTTCACCAGGCAAGTCT 3'; bFGF_f: 
5' CAAAAACGGGGGCTTCTT 3', bFGF r: 5' AGCCAGGTAACGGTTAGCAC 3') and sufficient water to $25 \mu \mathrm{L}$. A negative control was also included for each gene amplification assay. The $18 \mathrm{~S}$ rDNA (18S f: 5' ATGCGTGCATTTATCA GA 3'; 18S r: 5'AACTATCCCGTCTGCAAG 3') was used as an internal control. The PCR cycling conditions were: $10 \min 95^{\circ} \mathrm{C}$; 40 cycles: $15 \operatorname{seg} 95^{\circ} \mathrm{C}, 30 \operatorname{seg} 60^{\circ} \mathrm{C}, 15 \operatorname{seg} 72{ }^{\circ} \mathrm{C}$; followed by a dissociation curve. Threshold cycle $(\mathrm{Ct})$ was measured and a relative change in the expression level of one specific gene was presented as $2^{-\Delta \Delta \mathrm{Ct}}$.

\subsection{Statistical analysis}

Data are expressed as the mean \pm SEM performed three times in triplicate. The data presents normal distribution and homogeneity of variances. These conditions had been proved by the Shapiro-Wilk and Bartlett test, respectively. The statistical analysis was performed with Student's t-test or one-way analysis of variance (ANOVA) with Bonferroni's Multiple Comparison Test as indicated in the figure legends. A p value less than 0.05 was considered statistically significant.

\section{Results}

To verify if pravastatin affects cell cycle replication, firstly, we assess the cell viability. We observed a decreased at cells numbers after the addition of pravastatin only at higher concentrations $(0.6 \mu \mathrm{M}$ and $0.9 \mu \mathrm{M})$. Pravastatin at $0.3 \mu \mathrm{M}$ was not able to affect cell viability. Interestingly, the concentration of $0.6 \mu \mathrm{M}$ and $0.9 \mu \mathrm{M}$ promoted cytostatic effect only after 72 hours of incubation, showing that this effect is both, concentration/time dependent (Figure 1).

Thereafter, we observe the action of pravastatin in the cycle by the methodology of PI. The incubation of the MM cell with pravastatin $(0.6 \mu \mathrm{M}$ and $0.9 \mu \mathrm{M})$, result in an increase in the number of cells in $\mathrm{G} 0 / \mathrm{G} 1$ cell cycle phase after 72 hours. The lower concentration of pravastatin $(0.3 \mu \mathrm{M})$ was insufficient to provide cell cycle arrest in a significant quantity of cells. The Figure 2 shows the G0/G1 cell cycle arrest. It's important to emphasize that these cell lineage is well known to have different size and shape, and to concentrate the major amount of cells in the $\mathrm{G} 2 / \mathrm{M}$, and to be able to synthesize and secrete IL-6.

The main factors released by the cell line and that are involved at proliferation of MM cell were evaluated. These four important factors are shown at Figure 3. The three periods, $24 \mathrm{~h}, 48 \mathrm{~h}$ and $72 \mathrm{~h}$ were evaluated. For sake of clarity the results shown are for $48 \mathrm{~h}$ of treatment. Pravastatin reduced VEGF and bFGF levels at supernatant of the cells, meanwhile did not cause changes in the secretion of IL- 6 and TGF $\beta$.

To confirm the results obtained with the ELISA we performed a qRT-PCR. In addition to the factors studied we also evaluated the expression of HMGCoA reductase gene. Pravastatin was able to increase only VEGF mRNA levels. Interestingly, the levels of HMGCoA have not changed with the use of pravastatin in the studied cells (Figure 4).

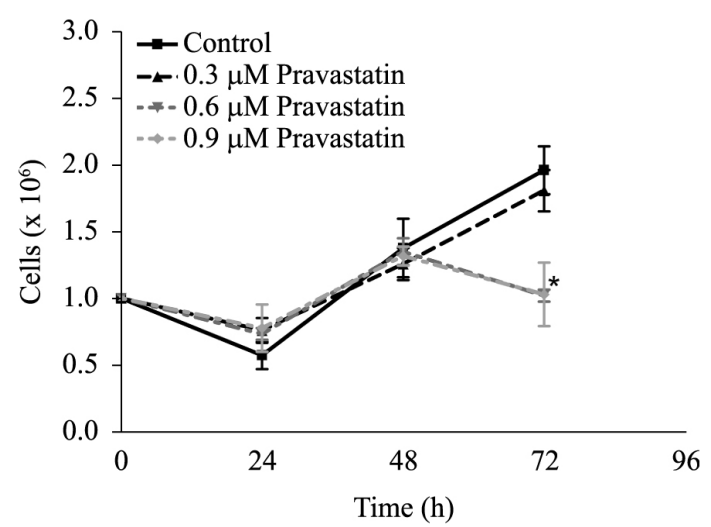

Figure 1. Pravastatin reduces the number of viable cells in cultured Multiple Myeloma after 72 hours. Cells were cultured in the presence of the pravastatin, or vehicle for 3 days. Three wells of each condition were subjected to the Trypan Blue assay. Data are expressed as mean and standard error of the mean. Statistical analysis was performed using ANOVA followed by Bonferroni's Multiple Comparison Test. $* \mathrm{p}<0.05$ compared with the control group.

\section{Discussion}

The literature has reported different effects of statins in neoplastic cells, such as induction of apoptosis, decreased cell proliferation, arrest in $\mathrm{G} 0 / \mathrm{G} 1$ cell cycle and reduction of inflammatory cytokines. These effects have been tested in different cancers such as melanoma (Favero et al., 2010), thyroid cancer (Zhong et al., 2011) osteosarcoma (Tsubaki et al., 2011), hepatocellular carcinoma (Tijeras-Raballand et al., 2010). Additionally, several studies have shown that statins reduce cell proliferation in hematopoietic malignancies such as chronic lymphocytic leukemia (Podhorecka et al., 2010), acute promyelocytic leukemia NB4 (Sassano et al., 2007) and MM (Otsuki et al., 2004). Wong et al. (2007) showed that the sensitivity of cells to lovastatin is associated with a specific profile of genetic abnormalities. Another study (Clendening et al., 2010) attributed the sensitivity of cancer cells to statins dysregulation of the mevalonate pathway. After the evaluation of a large panel of MM cell Wong et al. (2007) found that $50 \%$ of the studied strains are sensitive to lovastatin.

A Japanese study (Otsuki et al., 2003) observed that about a third of the strains tested were MM pravastatin sensitive. Different strains of melanoma showed varied susceptibility to statins, the effects related to cell cycle arrest and apoptosis (Zhong et al., 2011). This effect was observed in other cancers (Xiang et al., 2011) where lovastatin inhibited cell proliferation in ATC strains aggressive thyroid cancer in vitro, raising the level of p27 protein, which inhibits the activity of CDK2 holding the cells in G1 phase.

Other effects attributed to statins refer to modulation of inflammatory mediators and growth factors. Here, we showed that pravastatin reduced VEGF and bFGF levels when compared to control cells. Despite of involvement of 


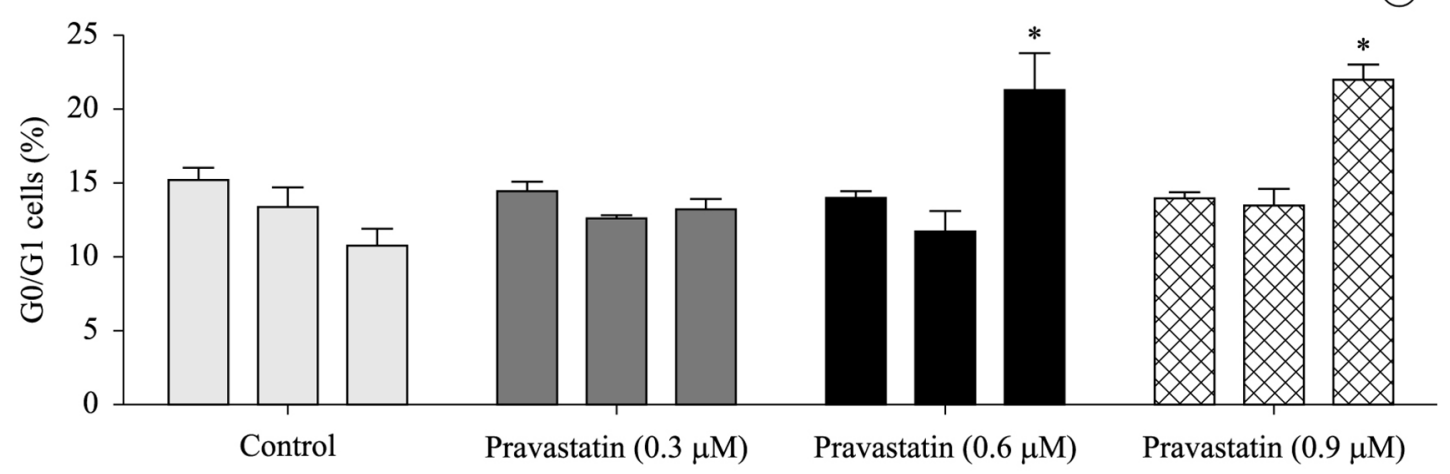

(b)

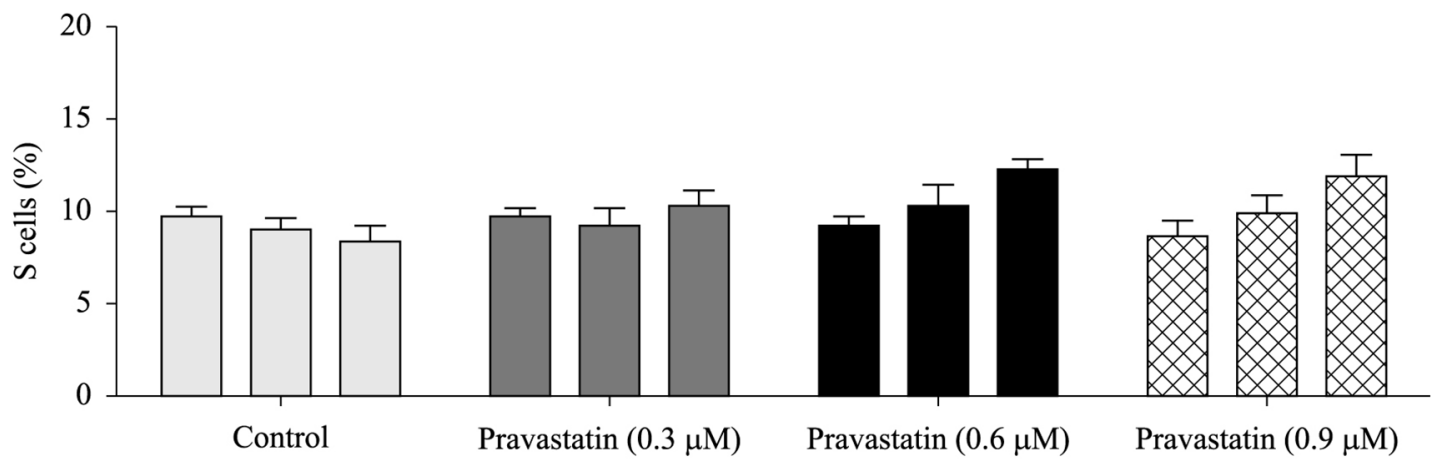

(c)

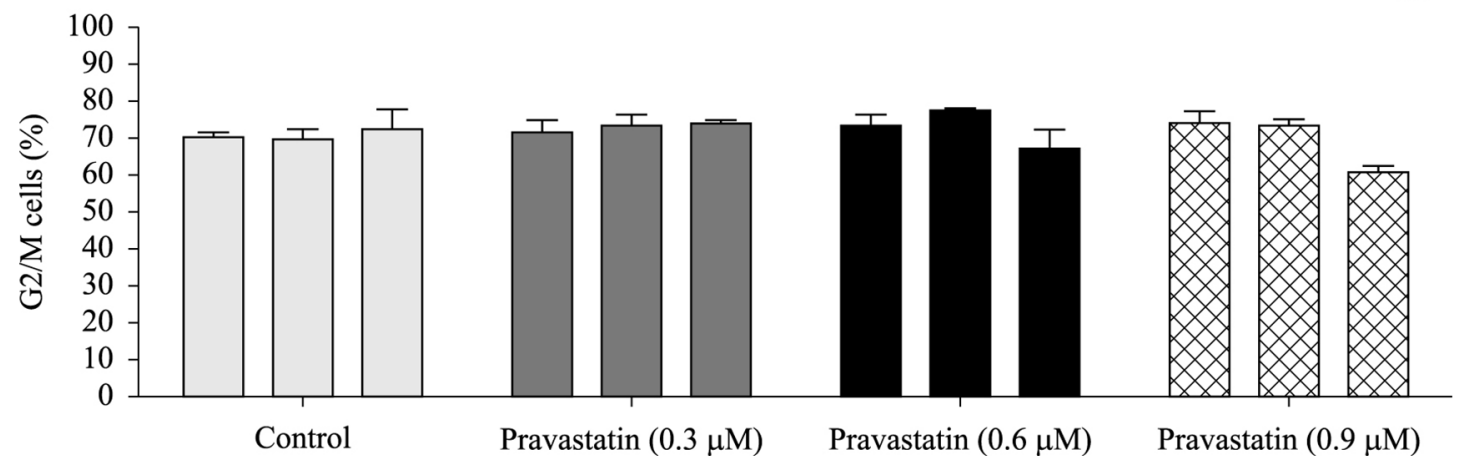

Figure 2. Pravastatin induces G0/G1 cell cycle arrest. Flow cytometry Cell cycle analysis, using propidium iodide. (a) Percentage of cell in G0/G1 phase; (b) Percentage of cells in Synthesis Phase; (c) Cells on G2/M Phases. Each bar represents the mean and standard error of the mean of a representative assay performed three times in triplicate. The first bars are 24h, the second $48 \mathrm{~h}$ and the third bar 72h. (ANOVA followed by Bonferroni's Multiple Comparison Test).

IL-6 at the progression of multiple myeloma, the mRNA and protein levels of this cytokine was not changed by pravastatin treatment. This agrees with a similar result obtained before by other study (Otsuki et al., 2003). Likewise, despite the extensive evidence, showing that TGF- $\beta$ is a key player in cell proliferation, differentiation and apoptosis, pravastatin effect on MM cells cycle is no explained by changes in this growth factor production. Nevertheless, we cannot rule out the possibility that pravastatin affect the signaling pathway of IL- 6 and TGF- $\beta$.

The reduction of VEGF and FGF was observed by others (Cho et al., 2008) who note the reduction of VEGF in vitro and in vivo. Several studies shows (Zhong et al., 2011) that statins reduce mRNA of FGF, HGF and TGF $\beta$ in osteosarcoma cells in culture. These growth factors are due to inhibition of GGPP (geranyl-geranyl pyrophosphate), preventing the location of Ras to the plasma membrane and subsequent activation of pathways MEK/ERK (extracellular signal controlled by the kinase) and $\mathrm{PI} 3 \mathrm{~K} / \mathrm{AKT}$ (phosphatidylinositol kinase 3 / protein kinase $\mathrm{C}$ ).

In conclusion, the results of our work showed that Pravastatin induces: cell cycle arrest at G0/G1 allied to a decrease in cell growth and survival in a MM cell line; 

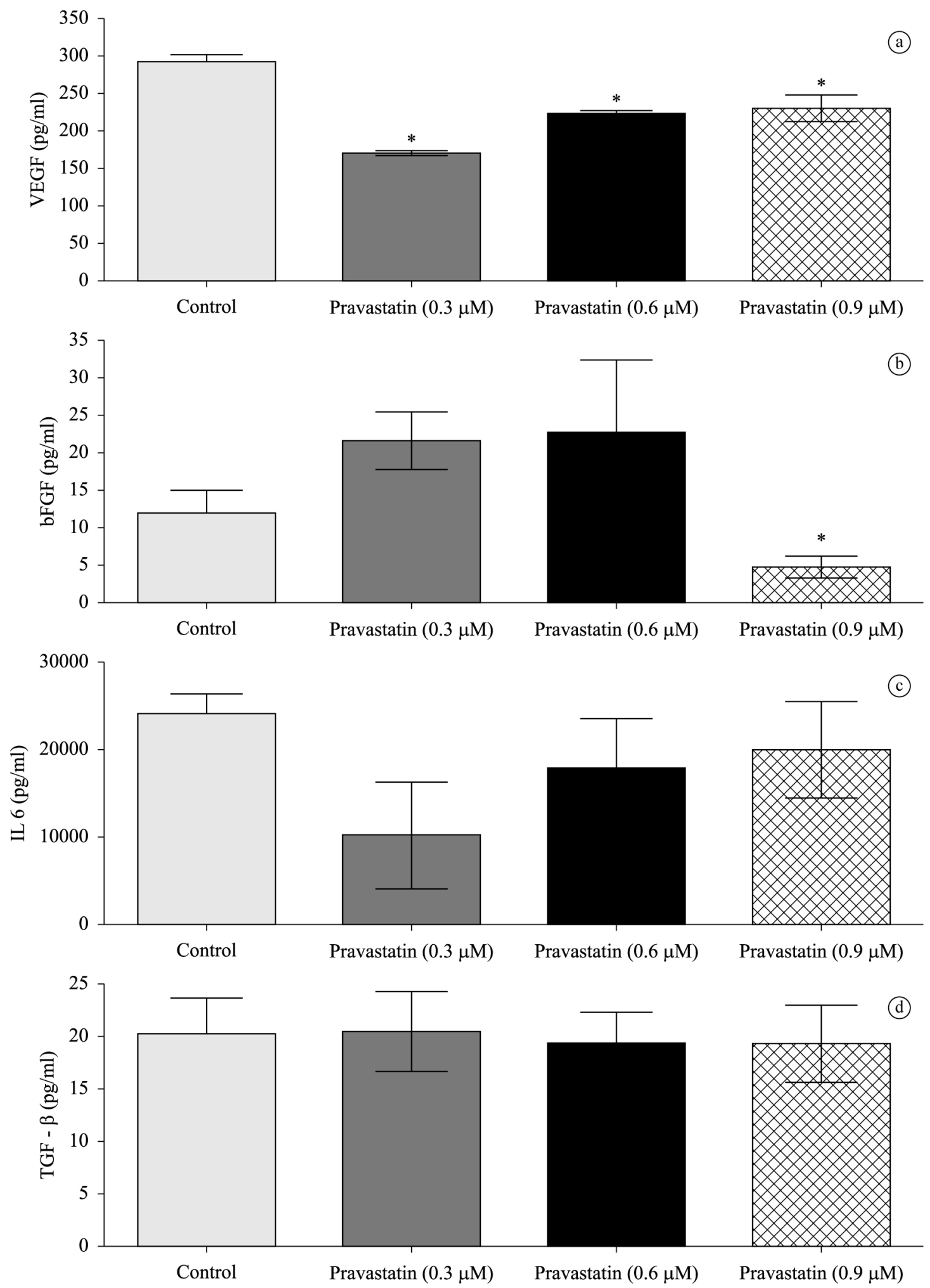

Figure 3. Pravastatin induces the loss of VEGF and FGF. Evaluation of different factors in the supernatant culture of MM treated with Pravastatin in different concentrations (ELISA assay). The result shown is representative of $48 \mathrm{~h}$ of treatment in triplicate. Each bar represents the mean with their standard deviations. Statistical analysis was performed using Student's t-test. $* \mathrm{p}<0.05$ compared with the control group. 

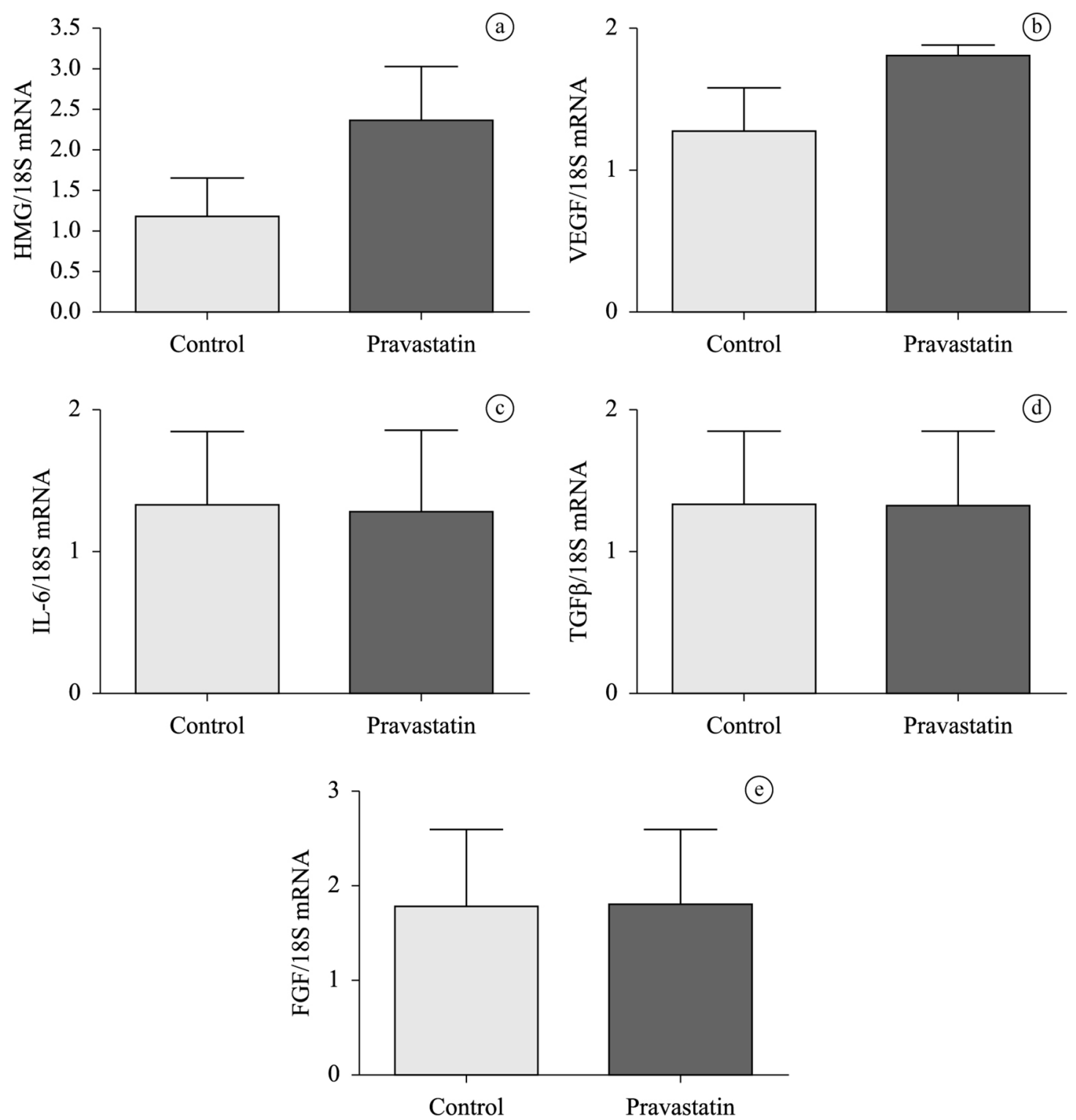

Figure 4. Pravastatin not change the expression of HMG CoA reductase. Evaluation of different mRNA by qRT PCR. The result shown is representative of $48 \mathrm{~h}$ of treatment performed three times in triplicate. Threshold cycle $(\mathrm{Ct})$ was measured and a relative change in the expression level of one specific gene was presented as $2^{-\Delta \Delta C t}$ Each bar represents the mean with their standard deviations. Statistical analysis was performed using Student's t-test. $* \mathrm{p}<0.05$ compared with the control group.

decrease in VEGF and bFGF; did not change IL-6 and TGF $\beta$. These effects should be, in part, due to pleiotropic effects and not by the 3-Methyl-Glutaryl Coenzyme A reductase inhibition.

\section{References}

BALAKUMARAN, A., ROBEY, P.G., FEDARKO, N. and LANDGREN, O., 2010. Bone marrow microenvironment in myelomagenesis: its potential role in early diagnosis. Expert Review of Molecular Diagnostics, vol. 10, no. 4, pp. 465-480. http://dx.doi.org/10.1586/erm.10.31. PMid:20465501.
CHO, S.J., KIM, J.S., KIM, J.M., LEE, J.Y., JUNG, H.C. and SONG, I.S., 2008. Simvastatin induces apoptosis in human colon cancer cells and in tumour xenografts, and attenuates colitis-associated colon câncer in mice. International Journal of Cancer, vol. 123, no. 4, pp. 951-957. http://dx.doi.org/10.1002/ ijc.23593. PMid:18521906.

CLENDENING, J.W., PANDYRA, A., BOUTROS, P.C., EL GHAMRASNI, S., KHOSRAVI, F., TRENTIN, G.A., MARTIROSYAN, A., HAKEM, A., HAKEM, R., JURISICA, I. and PENN, L.Z., 2010. Dysregulation of the mevalonate pathway promotes transformation. National Academy of Sciences of the America, vol. 107, no. 34, pp. 15051-15056. http://dx.doi. org/10.1073/pnas.0910258107. PMid:20696928. 
FAVERO, G.M., OTUKI, M.F., OLIVEIRA, K.A., BOHATCH JUNIOR, M.S., BORELL, P., BARROS, F.E., MARIA, D.A., FERNANDES, D. and BYDLOWSKI, S.P., 2010. Simvastatin impairs murine melanoma growth. Lipids in Health and Disease, vol. 16.

GADÓ, K., SILVA, S., PÁLÓCZI, K., DOMJÁN, G. and FALUS, A., 2001. Mouse plasmocytoma: experimental modelo of human multiple myeloma. Haematologica, vol. 86, no. 3, pp. 227-236. PMid:11255268.

GAUTHAMAN, K., MANASI, M. and BONGSO, A., 2009. Statins inhibit the growth of variant human embryonic stem cells and câncer cells in vitro but not normal human embryonic stem cells. Journal British Pharmacology, vol. 157, no. 6, pp. 962-973. http:// dx.doi.org/10.1111/j.1476-5381.2009.00241.x. PMid:19438511.

GIULIANI, N. and RIZZOLI, V., 2007. Myeloma cells and boné marrow osteoblast interactions: role in the development of osteolytic lesions in multiple myeloma. Leukemia \& Lymphoma, vol. 48, no. 12, pp. 2323-2329. http://dx.doi.org/10.1080/10428190701648281. PMid:18067006.

GRECO, C., VITELli, G., VERCILlO, G., VONA, R., GIANNARELLI, D., SPERDUTI, I., PISANI, F., CAPOLUONGO, E., PETTI, M.C. and AMEGLIO, F., 2009. Reduction of serum IGF-I levels in patients affected with monoclonal gammopathies of undetermined significance or multiple myeloma: comparision with bFGF, VEGF and k-ras gene mutation. Journal of Experimental \& Clinical Cancer Research, vol. 28, no. 1, pp. 35. http://dx.doi. org/10.1186/1756-9966-28-35. PMid:19284554.

LUDWIG, H., BEKSAC, M., BLADÉ, J., BOCCADORO, M., CAVENAGH, J., CAVO, M., DIMOPOULOS, M., DRACH, J., EINSELE, H., FACON, T., GOLDSCHMIDT, H., HAROUSSEAU, J.L., HESS, U., KETTERER, N., KROPFF, M., MENDELEEVA, L., MORGAN, G., PALUMBO, A., PLESNER, T., SAN MIGUEL, J., SHPILBERG, O., SONDERGELD, P., SONNEVELD, P. and ZWEEGMAN, S., 2010. Current multiple myeloma treatment strategies with novel agents: a european perspective. The Oncologist, vol. 15, no. 1, pp. 6-25. http://dx.doi.org/10.1634/theoncologist.2009-0203. PMid:20086168.

MA, S. and MA, C.C., 2011. Recent development in pleiotropics effects of statins on cardiovascular disease trhrough regulation of transforming growth factor-beta superfamily. Cytokine \& Growth Factor Reviews, vol. 22, no. 3, pp. 167-175. PMid:21700485.

MEDINA, M.W., 2010. The relationship between HMGCR genetic variation alternative splicing and statin eficacy. Discovery Medicine, vol. 9, no. 49, pp. 495-499. PMid:20587337.

MUSSO, A., ZOCCHI, M.R. and POGGI, A., 2011. Relevance of the mevalonate biosynthetic pathway in the regulation of bone marrow mesenchymal stromal cell-mediated effects on T-cell proliferation and B-cell survival. Haematologica, vol. 96, no. 1, pp. 16-23. http://dx.doi.org/10.3324/haematol.2010.031633. PMid:20884711.

OTSUKI, T., SAKAGUCHI, H., ETO, M., FUJI, T., HATAYAMA, T., TAKATA, A., TSUJIOKA, T., SUGIHARA, T. and HYODOH, F., 2003. IL-6 a key factor in growth inhibition of human myeloma cells induced by pravastatin, en HMG-CoA reductase inhibitor. International Journal of Oncology, vol. 23, no. 3, pp. 763-768. PMid:12888915.

OTSUKI, T., SAKAGUCHI, H., HATAYAMA, T., FUJII, T., TSUJIOKA, T., SUGIHARA, T., TAKATA, A., HYODOH, F. and ETO, M., 2004. Effects of an HMG-CoA reductase inhibitor, simvastatin, on human myeloma cells. Oncology Reports, vol. 11, no. 5, pp. 1053-1058. PMid:15069546.

PENG, H., WEN, J., LI, H., CHANG, J. and ZHOU, X., 2011. Drug inhibition profile prediction for NFאB pathway in multiple myeloma. Public library of Science, vol. 6, no. 3.
PODHORECKA, M., HALICKA, D., KLIMEK, P., KOWAL, M., CHOCHOLSKA, S. and DMOSZYNSKA, A., 2010. Simvastatin and purine analogs have a synergic effect on apoptosis of chronic lymphocytic leukemia cells. Annals of Hematology, vol. 89, no. 11, pp. 1115-1124. http://dx.doi.org/10.1007/s00277-010-0988-z. PMid:20499237.

RAAB, M.S., PODAR, K., BREITKREUTZ, I., RICHARDSON, P.G. and ANDERSON, K.C., 2009. Multiple myeloma. Lancet, vol. 374, no. 9686, pp. 324-339. http://dx.doi.org/10.1016/S01406736(09)60221-X. PMid:19541364.

ROY, M., KUNG, H.J. and GHOSH, P.M., 2011. Statins and prostate cancer: role of cholesterol inhibition vs. prevention of small GTPbinding proteins. American Journal of Cancer Research, vol. 1, no. 4, pp. 542-561. PMid:21984972.

SASSANO, A., KATSOULIDIS, E., ANTICO, G., ALTMAN, J.K., REDIG, A.J., MINUCCI, S., TALLMAN, M.S. and PLATANIAS, L.C., 2007. Supressive effects of statin on acute promyelocytic leukemia cells. Cancer Research, vol. 67, no. 9, pp. 4524-4532. http://dx.doi.org/10.1158/0008-5472.CAN-06-3686. PMid:17483369.

TIJERAS-RABALLAND, A., HAINAUD-HAKIM, P., CONTRERES, J.O., GEST, C., LE HENAFF, C., LEVY, B.I., POCARD, M., SORIA, C. and DUPUY, E., 2010. Rosuvastatin counteracts vessel arterialisation and sinusoid capillarisation, reduces tumour growth, and prolongs survival in murine hepatocelular carcinoma. Gastroenterology Research and Practice, vol. 2010, pp. 640797. http://dx.doi.org/10.1155/2010/640797. PMid:21528105.

TSUBAKI, M., YAMAZOE, Y., YANAE, M., SATOU, T., ITOH, T., KANEKO, J., KIDERA, Y., MORIYAMA, K. and NISHIDA, S., 2011. Clockade of the Ras/MEK/ERK and Ras/PI3K/AKT pathways by statins reduces the expression of bFGF, HGF and TGF $\beta$ as angiogenic factors in mouse osteossarcoma. Cytokine, vol. 54, no. 1, pp. 100-107. http://dx.doi.org/10.1016/j.cyto.2011.01.005. PMid:21292498.

VINDELOV, L.L., CHRISTENSEN, I.J. and NISSEN, N.I., 1983. A detergent-trypsin method for the preparation of nuclei for flow cytometric DNA analysis. Cytometry, vol. 3, no. 5, pp. 323-327. http://dx.doi.org/10.1002/cyto.990030503. PMid:6188586.

WONG, W.W., CLENDENING, J.W., MARTIROSYAN, A., BOUTROS, P.C., BROS, C., KHOSRAVI, F., JURISICA, I., STEWART, A.K., BERGSAGEL, P.L. and PENN, L.Z., 2007. Determinantes of sensivity to lovastatin-induced apoptosis in multiple myeloma. Molecular Cancer Therapeutics, vol. 6, no. 6, pp. 1886-1897. http://dx.doi.org/10.1158/1535-7163.MCT-060745. PMid: 17575117

XIANG, Y., REMILY-WOOD, E.R., OLIVEIRA, V., YARDE, D., HE, L., CHENG, J.Q., MATHEWS, L., BOUCHER, K., CUBITT, C., PEREZ, L., GAUTHIER, T.J., ESCHRICH, S.A., SHAIN, K.H., DALTON, W.S., HAZLEHURST, L. and KOOMEN, J.M., 2011. Monitoring a nuclear factor-kB signature of drug resistance in multiple myeloma. Molecular and Celular Proteomic, vol. 10, no. 11.

ZHAN, F., HUANG, Y., COLLA, S., STEWART, J.P., HANAMURA, I., GUPTA, S., EPSTEIN, J., YACCOBY, S., SAWYER, J., BURINGTON, B., ANAISSIE, E., HOLLMIG, K., PINEDA-ROMAN, M., TRICOT, G., VAN RHEE, F., WALKER, R., ZANGARI, M., CROWLEY, J., BARLOGIE, B. and SHAUGHNESSY JUNIOR, J.D., 2006. The molecular classification of multiple myeloma. Blood, vol. 108, no. 6, pp. 2020-2028. http://dx.doi.org/10.1182/ blood-2005-11-013458. PMid:16728703.

ZHONG, W., HSU, S.P., HO, P.Y., LIANG, Y.C., CHANG, T.C. and LEE, W.S., 2011. Lovastatin inhibits proliferation of anaplasic thyroid câncer cells through up-regulation of $\mathrm{p} 27$ by interfering with the Rho/ROCK-mediated pathway. Biochemical Pharmacology, vol. 82, no. 11, pp. 1663-1672. http://dx.doi.org/10.1016/j. bcp.2011.08.021. PMid:21907187. 